\title{
RELIGION AND THE QUALITY OF LIFE IN URBAN COMMUNITIES
}

\author{
Mihai PASCARU1
}

DOI: $10.35782 / J C P P .2019 .3 .05$

\begin{abstract}
The study first reviews some research and analysis of the relationships between religion and dimensions of the quality of life. It focuses thereafter on particular investigations of these relationships as they apply to several neighbourhoods in the city of Alba Iulia, Romania, where associations between religious confession and indicators of the quality of life like liveability, incomes and food quality have recently been polled. The observations lead to the conclusion that several religious communities are confronting themselves with problems that are similar and that might be alleviated through a promotion of strategic ecumenism.
\end{abstract}

Key words: confession, quality of life, liveability, food quality, strategic ecumenism

\section{Introduction}

Studies of the connections between religion and the quality of life often use institutional or spiritual variables like religiosity. Peterson \& Webb (2006) concluded that several American researchers realised an important conceptual progress when they moved away from institutional indicators of religion (like religious denomination, faith or ritual) towards the new concept of religiosity, as expressing the relationship between ego and God. They concluded that religiosity was strongly correlated with some of the main dimensions of wellbeing: overall happiness, life satisfaction, life excitement and marital happiness. This correlation was stronger than the one between wellbeing and ordinary variables like race, income, civil status and church attendance (Peterson \& Webb, 2006: 109). The two authors also considered that studies of particular denominations or of particular sets of spiritual practices bring a macro-vision of the quality of the confessional life, or of the life in general, in society. This vision, the authors remarked, could be focused on the objective dimension of the quality of life (the standard of living) or on the more subjective aspects, like the general happiness of the population. Previous American analyses, which concluded that the concept of a

1 PhD Professor, "1 Decembrie 1918" University of Alba Iulia, Romania; E-mail: mihaipascarupag@gmail.com 
good life in the United States is based in a large extent on the Judeo-Christian ideas, are also mentioned (Peterson \& Webb, 2006: 110).

The starting point of our analysis is that in a more or less formal manner, religions are determining the spiritual and social life of communities that differ in their quality of life. There is no intention to examine the relationships between religious ideology and the quality of life, nor between religiosity and the standard of living. We only intend to sketch some characteristics of religious communities in a territory and maybe to identify some of the burdens on existing churches, at least through their followers, in the territory under scrutiny. More practical aspects of such an endeavour will be highlighted in the conclusions.

The analysis is based on data that was collected with the occasion of a Local Development Strategy survey taken in the city of Alba Iulia, Romania. For the purpose of the survey, a territory made up of several residential districts surrounding a sociallymarginalised Roma population area was delimited, area which was also used in previous investigations (Marina, 2010). The survey took place in the fall of 2017, being administered by a team including the author of this paper and lecturers Vlad Millea, $\mathrm{PhD}$, and Rodica Silvia Stânea, $\mathrm{PhD}$, of the "1 Decembrie 1918" University of Alba Iulia. Out of the datasets obtained, we will be examining here only the associations between religious confession of the inhabitants and three other indicators: liveability, household income and quality of food.

As previously mentioned, our conclusions will make some practical references, but will also suggest avenues open for further research.

\section{World Research on Religion and Quality of Life}

In a study on religion and poverty in Brazil comparing the real-life experience of Brazilian Pentecostal Church members with that of Romano-Catholic ones, Mariz (1992: 63) concluded that the two were more similar than what the otherwise acute differences in respective religious ideologies would predict. Mariz noticed that both movements promoted closeness to God, self-respect, offered national support networks through their purpose, developped leadership abilities, promoted literacy and both encouraged a sober and ascetic lifestyle. The long-term consequences of the economic and political behaviour of the members could have been a lot less different than what most observers would predict. This aspect was visible especially in the management of the social and economic support, even though it was inter-individual in the case of Pentecostals and communitarian in the case of traditional communities (Mariz, 1992: 67).

Remaining in the Latino American space, we can also mention Henri Gooren, who, while studying connections between liberation theology and quality of life in Guatemala, remarked that at the end of the 60's and beginning of the 70's, the Romano-Catholic liberation theology movement appeared to gain a lot more momentum than evangelical Protestantism in Latin America. Liberation theology claimed that The Kingdom of God could be established on Earth through struggle for social justice and against poverty. Towards that goal, social order should first be 
analysed by the poor (Gooren, 2002: 29). Nevertheless, Gooren remarked, the poor preferred to join non-Romano-Catholic confessions in the detriment of those named Christian Base Communities or of other denominations promoting liberation theology. In his search for an explanation, Gooren found that the non-Romano-Catholic confessions promoted elements of ascetism and self improvement, which conferred important instruments to the Guatemalan poor for economic and spiritual improvements in their quality of life (Gooren, 2002: 29). The adherence to nonRomano-Catholic churches came also with additional advantages. They were legitimising the partial withdrawal from own household and family as a possible solution to some of the social problems. The outside world was considered harsh, sinful and dominated by exploitation, crime and corruption. Since the contact with it cannot be avoided, it should then be subjected to the rigorous morality of those churches. The adherence to church was also stimulating new abilities and responsibilities and offered the opportunity for the development of social support networks in case of sickness or unemployment. Moreover, both leaders and followers of the movements were coming from the same social strata and talked the same language (Gooren, 2002: 40). Accepting capitalism as a given, the author observed, the Guatemalan poor build their own liberation theology in struggling to cope with daily problems of poverty, exploitation, ignorance and alcoholism. In this new liberation theology, Gooren concluded, "God was not so much a companion in the quest for a better society, but rather in the quest for a better self” (Gooren, 2002: 40).

On the other side of the world, in India, data on poverty and religion displays wide variations for different groups. The Buddhists had the highest incidence of poverty (40\%), followed by Hindu (29\%) and Muslims (28\%). Christians and Sikhs had lower rates $(16 \%$, respectively $5 \%$ ) and Jainists ranking best at $2 \%$. Thus the Buddhist minority was the poorest, the two largest Hindu and Muslim majorities had average rates and three other minorities (Christians, Sikhs and Jainists) had the lowest rates of poverty (Thorat, 2010: 49). The variables that explained such findings were a better education of Christians and a more inclination towards commerce and entrepreneurship of other minorities.

Looking at the correlations between the religious affiliation of the heads of the households and poverty in Africa, Anyanwu (2013: 32) found that poverty levels in Nigeria varied with religion. In 2004, the incidence of poverty based on the religion of household head were $40.41 \%$ for Christians, $68.81 \%$ for Muslims, $56.61 \%$ for traditional religions and $48.17 \%$ for others. In Kenia, research undertaken by Achia, Wangombe and Khadioli (2010: 42) found association between poverty and the following predictor variables: ethnicity, religion, number of household members, highest level of education attained, the age of household head and the type of place of residence. The results showed that the religious were less poor overall $(20.7 \%$ on average) than those without religion $(74.2 \%)$. More so, religion had significance over the socio-economic status of the household head as follows: 1) Protestant heads (or other Christian denomination except Romano-Catholic) predicted higher probabilities for poverty than Romano-Catholic heads; 2) Muslim heads predicted higher probability for poverty than Romano-Catholic heads (Achia, Wangombe \& Khadioli, 2010: 43). In North America, Ludwig and Mayer (2006: 181) concluded that lower income 
Americans better identified with a religious confession, went to church more frequently and prayed more often than higher income ones.

In researching the connections between religion and the quality of life, we believe that one should also pay attention to the links between religion and economic attitudes. As Guiso, Sapienza and Zingales (2003) remarked, there is an active debate on the impact of religion on believers' economic attitudes ever since Max Weber. The authors used World Values Survey towards the purpose of finding such connections. Their main conclusion was that religious faith was closely associated with a favourable attitude towards prosperity. Overall, Christian beliefs appeared more positively associated with favourable attitudes towards higher incomes and economic growth (Guiso, Sapienza \& Zingales, 2003: 225). Some significant findings include: 1) Atheists had less positive attitudes towards markets and perception of their correctness (p. 249); 2) Religious people were less likely to give up equality for certain incentives and were less favourable to private property in general, but frequent churchgoers were more likely to do that and more open to private property in particular; 3) Religious people held more dearly onto the belief that poverty comes from laziness and lack of will than from an unfair social treatment (p. 250).

Other research on religion and economic growth lead to contradictory results. Some findings lead to the conclusion that most religions with the exception of RomanoCatholicism had negative influences on economic growth while other had found that some religions like Islam and Confucianism had more positive influence than RomanoCatholicism. Some studies identified a negative influence of religion in Islam-dominated countries, other a positive one (Offutt, Probasco \& Vaidyanathan, 2016: 3).

In Europe, research undertaken by Lepianka, Gelissen and Van Oorschot (2010) highlighted, among others, the fact that differences in the manner in which poverty was attributed were directly related to the existence of a Romano-Catholic tradition in the respective country. Thus, they found it more likely that, in Romano-Catholicallyinfluenced countries, poverty would be more attributable to factors outside poor man's control, such as social injustice and the lack of opportunities (Lepianka, Gelissen \& van Oorschot, 2010: 68).

Under the same frame of reference, Hunt (2002: 810) found out that in the American space, Protestants and Romano-Catholics displayed stronger individualistic convictions (attributing more responsibility to personal merit), Jews and others held more structural beliefs (poverty being related to social determinants), while Romano-Catholics and Jews displayed more fatalism (attributing poverty more to bad luck or to lack of opportunity). In the same frame of reference, an older study by Norman T. Feather (1974), who looked at some Australian and American cases, is worth mentioning.

The literature on the subject also includes several other important topics: 1) the relationship between religious belief and social inequalities (Keister, 2008); 2) the relationship between religion and some subjective aspects of wellbeing (Diener, Tai and Myers 2011); 3) the implications of religiosity on economic outcomes (Gruber, 2005); 4) the relationship between religion and social policies (Kahl, 2005); 5) religious organisations and the fight against poverty (Jawad, 2008). 
In Romanian sociology, Sandu (2015: 204-205) treated religious confession (specifically the Greek-Orthodox proportion of the population) as a defining dimension of cultural zones seen as 'regions of maximal homogeneity' and which, in fact, constitute groups of counties with socio-cultural similarities. In historical context, these cultural zones are associated to the development processes.

Research in which we were directly involved in the past examined aspects of relationships between religion and civil society (Pascaru \& Butiu, 2009) or environmental concerns (Buțiu \& Pascaru 2014). An active participant in our research, Moldovan (2010) studied the connections between religion and entrepreneurial profile of rural inhabitants.

\section{Research in the City of Alba Iulia, Romania}

\section{Population Profile}

As previously mentioned, our analysis is based on a research study undertaken in Alba Iulia, the capital city of Alba county, Romania. The actual area under study included the neighbourhoods Ampoi I, Ampoi II, Ampoi III, and Cetate, where religious selfidentification was as follows: 1.2\% non-religious, 81.5\% Greek-Orthodox, $11.2 \%$ Pentecostal, 1.5\% Greek-Catholic (i.e. Eastern-Catholic), 1.4\% Romano-Catholic and $1.1 \%$ Jehovah's Witnesses. Those with less than $1 \%$ were Baptists $(0.6 \%)$, Protestants $(0.5 \%)$, Adventists $(0.5 \%)$ and other with unspecified religion $(0.8 \%)$. The predominant ethnic group were Romanians at $77.9 \%$, followed by Romany at $20.3 \%$ and Hungarians at $1.8 \%$.

Out of the $1.2 \%$ non-religious respondents, $62.4 \%$ were Romanians and $37.6 \%$ Romany. Out of the Greek-Orthodox, $85.3 \%$ identified themselves as Romanians, $14.5 \%$ as Romany and $0.2 \%$ as ethnic Hungarians. Greek-Catholics were $100 \%$ Romanians and Protestants were 100\% Hungarians. Romano-Catholics were 55.8\% Romanians and 44.2\% Hungarians. Baptists declared themselves 74.4\% Romanians and $25.5 \%$ Hungarians. Pentecostals self-identified as 24.3\% Romanians, $74.2 \%$ Romany and 1.5\% Hungarians. Adventists were 65.6\% Romanians and 34.4\% Romany. Jehovah's Witnesses were $85.1 \%$ Romanians and $14.9 \%$ Romany. Of other, unspecified religions, 60.4\% were Romanians and 39.6\% Hungarians.

The median age of respondents was 50 . Younger than that were the non-religious at 40.9 years, Pentecostals at 42.1, Adventists at 44 and those of other religion at 47.2 years. At and over the average were the Greek-Catholic at 75.5, Romano-Catholics at 60.9, Protestants at 55.7 and Baptists and Jehovah's Witnesses both at 61.5 years of age. One may remark that the Greek-Orthodox were to the median age of the population, fact that can also be said in regard to other variables.

Out of the non-religious respondents, $48.8 \%$ were married and $12.8 \%$ each, in equal proportions, were common-law, divorced and widowed. The Greek-Orthodox were mostly married at $60.9 \%$. Fifty percent of Greek-Catholics and of Baptists were widowed and $50 \%$ of Baptists were married. Among the Romano-Catholics $44.2 \%$ were married. Protestants were split equally at $33.3 \%$ between married, divorced or of 
other civil status. The majority of Pentecostals (62.1\%) were married. Adventists were also split 33.3\% equally between married, divorced or "other" (including separated or single parents). Jehovah's Witnesses had the highest proportion of married respondents at $85.1 \%$. Also, those of "other" religion were mostly married at $74.4 \%$.

In terms of education, many of the non-religious (37.2\%) reached grade 10 and $24.4 \%$ graduated high school (i.e. grade 12). Greek-Orthodox graduated high school $(27.5 \%)$ and university $(18.3 \%)$. Approximately two thirds of Greek-Catholics and of RomanoCatholics were at least high school graduates $(67.9 \%$ and $66.3 \%$ respectively). Close to two thirds $(65.5 \%)$ of Protestants and $74.4 \%$ of Baptists had vocational education and none of the Baptists had graduated high-school. Most Pentecostals $(37 \%)$ were primary education (grades 1-4) graduates, followed by $20 \%$ secondary education (grades 5-8) and $14.4 \%$ with no formal education at all. All Adventists were grade 10 graduates. Out of all Jehovah's Witnesses, 27.6\% were high-school graduates and out of all "other" religions most were either grade 4 or university graduates, equally at $39.6 \%$.

Most of the respondents having no institutionalised education at all were Pentecostals $(20.1 \%)$. Most of the upper-educated were among the Greek-Orthodox, at $93.2 \%$. Baptists had a higher proportion of trades-level education (professional trades qualifications, $3.4 \%$ ).

As for the employment status, about half of the respondents without religion were wage earners, $37.6 \%$ were stay-at-home parents and $12.9 \%$ on social support. Of the Greek-Orthodox, $42.5 \%$ were gainfully employed, $35.5 \%$ pensioners, $10.2 \%$ stay-athome and $5.5 \%$ on social support. The majority $(89.6 \%)$ of the Greek-Catholics were pensioners and $10.4 \%$ salaried. The majority of Romano-Catholics were also pensioners $(55.8 \%)$, with rest of $44.2 \%$ earning incomes. Protestants were split in equal thirds, $33.3 \%$ earning steady incomes, $33.3 \%$ pensioners and $33.3 \%$ earning occasional or under-the-table incomes. Most Baptists (74.4\%) were pensioners and $25.6 \%$ inactive as preschoolers or dependents on other family members' incomes. Pentecostals, like the Greek-Orthodox, displayed a wide occupational diversity with $42.7 \%$ staying at home, $18 \%$ pensioners and $12.8 \%$ earning salaries. Pentecostals with other occupational status were $8.2 \%$ and those on social support payments $7.3 \%$. Jehovah's Witnesses were mostly pensioners $(70.7 \%)$ followed by stay-at-home $17.7 \%$ and on guaranteed minimum wage $14.7 \%$. Those of "other" religions were $39.6 \%$ salaried, $39.6 \%$ pensioners and $20.8 \%$ self-employed in agriculture.

The average number of household members of the whole sample was 2.8 persons. The average number of household members for each of the religion categories was 2.6 for non-religious, 2.7 for Greek-Orthodox, 2 for Greek-Catholic, 2.1 for RomanoCatholics, 2 for Protestants, 2.8 for Baptists, 3.5 for Pentecostals, 3 for Adventists, 3.29 for Jehovah's Witnesses and 2.4 for those of "other" religion.

Synthesizing these preliminary results, one should first notice that two religious communities include the majority of the inhabitants in the area under scrutiny: the Greek-Orthodox and the Pentecostal communities. The two communities have thus the highest probability of acquiring a diversity of members and of problems. It is no surprise that Romanians, Romany and Hungarians are to be found in both of them. 
Although far from us the intent of arguing for an ethnically-based determinism, we do not exclude the possibility that such an identity configuration can be also reflected in aspects concerning the quality of life, in spite of the noticeable differences in education levels of the Greek-Orthodox, who, in majority, were high-school graduates, and of Pentecostals, who in majority barely reached grade 8 . One should also keep in mind that the difference in age, the median age of the Greek-Orthodox being higher than the average of the sample, while that of the Pentecostals lower.

The Pentecostals and the Greek-Orthodox also displayed a wider occupational variety. A relatively low proportion of social support receivers, unlike Jehovah's Witnesses for example, was also noticed among Pentecostals and Greek-Orthodox. The "burden" of a large household falls mostly on the shoulders of the Pentecostals, Adventists and Jehovah's Witnesses, all with an average of three or more members.

In a preliminary estimate of the social realities in the area under observation, one could expect more social problems to be faced by neo-protestant communities (Pentecostal, Adventist and Jehovah's Witnesses), closely followed by the Greek-Orthodox community. The other communities are likely to deal with age-related problems and with the limited resources of pensioners, the Romano-Catholic, Protestant and Baptist communities probably facing similar needs.

\section{Dwelling and Amenities}

In terms of ownership, the place of residence was legally owned by one household member in: $49.9 \%$ cases where the respondent was non-religious, $71.9 \%$ of the GreekOrthodox, $89.6 \%$ of Greek-Catholic, $74.1 \%$ of Romano-Catholics, $65.6 \%$ of Protestants, $100 \%$ of Baptists, $31.8 \%$ of Pentecostals, $65.6 \%$ of Adventists, $56.8 \%$ of Jehovah's Witnesses and $79.2 \%$ of those of "other" religions. Social housing was used by $24.7 \%$ of the non-religious, $5.1 \%$ of Greek-Orthodox and $8.4 \%$ of Pentecostals. $12.9 \%$ of the non-religious, $7.1 \%$ of Greek-Orthodox, $46.8 \%$ of Pentecostals and $34.4 \%$ of Adventists lodged in residences that were not legally owned by any member of the household. Most of the rentals (12.95\%) were inhabited by Romano-Catholics, followed by Greek-Catholics at 10.4\% and Greek-Orthodox at $8.4 \%$.

The sample average living space of a household member was $21.6 \mathrm{~m} 2 /$ person. Less space than that was available to the non-religious $(12.1 \mathrm{~m} 2 /$ person), Protestants (15.7m2/person), Baptists (20.5m2/person), Pentecostals $(11.1 \mathrm{~m} 2 /$ person) and to those of "other" religion $(15.4 \mathrm{~m} 2 /$ person). More space was available to the Greek-Orthodox (22.7m2/person), Greek-Catholic (40.8m2/person), Adventists $(42.1 \mathrm{~m} 2 /$ person), and to Jehovah's Witnesses ( $23 \mathrm{~m} 2 /$ person). Electric power was not available to $12.9 \%$ of nonreligious, $4.4 \%$ of Greek-Orthodox and $8.6 \%$ of Pentecostals.

Natural gas was not available to $50 \%$ of non-religious, $17.5 \%$ of Greek-Orthodox, $55.2 \%$ of Pentecostals, $43.2 \%$ of Jehovah's Witnesses and $20.8 \%$ of those of "other" religion. Inside running water-toilets were not available to $7.3 \%$ of Greek-Orthodox and $23.4 \%$ of Pentecostals. Inside bathrooms were not available to $6.2 \%$ of GreekOrthodox and $20.9 \%$ of Pentecostals. Separate kitchens were not available to $62.4 \%$ of the non-religious, $15.4 \%$ of Greek-Orthodox, $11.6 \%$ of Romano-Catholics, $33.8 \%$ of Pentecostals and $43.2 \%$ of Jehovah's Witnesses. 
All Greek-Catholics, Romano-Catholics, Baptists, Adventists and those of "other" religion had refrigerators, whereas only $75 \%$ of the non-religious had refrigerators, $91.3 \%$ of Greek-Orthodox, $65.6 \%$ of Protestants, $86 \%$ of Pentecostals and $85.1 \%$ of Jehovah's Witnesses. Laundry machines were not available to $12.9 \%$ of the nonreligious, $10.7 \%$ of Greek-Orthodox and $14.3 \%$ of Pentecostals.

\section{Income and Expenses}

The average daily household member income in the area of study was EUR 7.83. Smaller incomes were declared by the non-religious (EUR 4.64), Protestants (EUR 6.45), Baptists (EUR 4.61), Pentecostals (EUR 7.00), Adventists (EUR 6.56) and Jehovah's Witnesses (EUR 2.66). The Greek-Orthodox (EUR 8.06), Greek-Catholics (EUR 8.91), Romano-Catholics (EUR 8.11) and those of "other" religion (EUR 11.55) had incomes greater than average.

Sample average monthly utility expense per household member was EUR 38.93. The Greek-Orthodox (EUR 39.59), Greek-Catholics (EUR 58.06), Romano-Catholics (EUR 41.91), Protestants (EUR 48.38), Baptists (EUR 43.01), Adventists (EUR 50.17), and those of "other" religion (EUR 47.49) spent over the average spent, while the nonreligious (EUR 21.59), Pentecostals (EUR 33.98) and the Jehovahss Witnesses (EUR 20.85) under the average.

Late payments during the previous 12 months were made by $75 \%$ of the non-religious, $31.5 \%$ of the Greek-Orthodox, $10.4 \%$ of the Greek-Catholic, $22.1 \%$ of RomanoCatholics, $50 \%$ of Protestants, $25.6 \%$ of Baptists, $72.6 \%$ of Pentecostals, $65.6 \%$ of Adventists and $66.7 \%$ of Jehovah's Witnesses.

Also during the previous 12 months, 50\% of the non-religious claimed they could not afford a proper heating bill; $25.2 \%$ of the Greek-Orthodox, $10.4 \%$ of Greek-Catholic, $33.7 \%$ of Romano-Catholics, $50 \%$ of Protestants and $50 \%$ of Baptists claimed the same problem. Among the Pentecostals $66.5 \%$ could not afford proper heating and also $34.4 \%$ of Adventists and $33.3 \%$ of Jehovah's Witnesses.

Single persons over 65 were $8.9 \%$ of all respondents. Out of these, $0.5 \%$ stated they could not make it on their own without help, $1.9 \%$ stated they have a hard time coping, $2.7 \%$ stated they have some difficulties, $3.2 \%$ said they manage fairly well and $0.6 \%$ said they are managing without problems. Both ends of the spectrum - the $0.5 \%$ who were not able to manage without help and the $0.6 \%$ who were managing without problems were entirely Greek-Orthodox.

\section{Grocery Expense and Food Quality}

Average food expense of a household member was EUR 56.45. More than the average was spent by the Greek-Orthodox (EUR 59.49), Greek-Catholics (EUR 92.16), Romano-Catholics (EUR 63.91), Adventists (EUR 82.43) and those of "other" religion (EUR 64.51). Less than the average was spent by Protestants (EUR 39.42), Baptists (EUR 56.45), Pentecostals (EUR 36.37), Jehovah's Witnesses (EUR 31.03), and by the non-religious (EUR 36.45). 
During the previous 12 months, some respondents bought food on credit, some did not: $25 \%$ of the non-religious, $15.4 \%$ of Greek-Orthodox, $49 \%$ of Pentecostals, $34.4 \%$ of Adventists and 17.2\% of Jehovah's Witnesses used credit; Greek-Catholic, RomanoCatholics, Protestants, Baptists and those of "other" religion did not.

Respondents were also questioned on how often they ate prepared food. Most of the non-religious $(62.4 \%)$ ate prepared food only once a day or less and $24.7 \%$ ate it only 2 3 times a week; only $12.9 \%$ ate it three times a day. The majority of Greek-Orthodox $(69.7 \%)$ also ate prepared food once a day or less and $23.5 \% 2-3$ times a week; only $6.8 \%$ ate it three times a day. $44.2 \%$ of Greek-Catholic ate cooked food once a day or less and $33.7 \%$ 2-3 times a week; $22.1 \%$ ate it three times a day. None of the RomanoCatholics ate prepared food three times a day. Most Baptists (74.4\%) ate cooked food once a day or less and $25.6 \%$ of them three times a day. Most Pentecostals ate it once a day or less and 30.3\% 2-3 times a week; only $4.3 \%$ ate it three times a day. Also, most Adventists $(65.6 \%)$ ate cooked food only once a day or less, followed by those who ate it 2-3 times a week. Half of Jehovah's Witnesses ate it once a day or less, 32.8\% 2-3 times a week and $17.2 \%$ three times a day. Those of "other" religion ate once a day or less in majority $(74.4 \%)$ and $25.6 \% 2-3$ times a week.

Households in which animal protein was not consumed daily were $50 \%$ of the-non religious, $56.8 \%$ of Greek-Orthodox, $50 \%$ of Greek-Catholic, $55.8 \%$ of RomanoCatholics, $74.4 \%$ of Baptists, $68.5 \%$ of Pentecostals, $65.6 \%$ of Adventists, $14.9 \%$ of Jehovah's Witnesses and all of those of “other" religion. In all Protestant households, animal protein was consumed daily.

\section{Conclusions and Openness}

We should first retain that the most affected by the uncertainty of their dwelling ownership were the Pentecostals and the Adventists. More than a third of them did not posses house property titles. In terms of personal living space, more problems were also associated with the Pentecostal and the non-religious communities. Although certain structural similarities between the Greek-Orthodox and Pentecostal communities can be noticed, major dwelling issues have only been identified in the Pentecostal community. The situation of the non-religious cannot be ignored either.

One relevant indicator for the quality of life is the availability of running water bathrooms inside homes. Pentecostal households were noticeably lacking this feature. Pentecostals were confronted with other scarceness too, like the lack of refrigerators and laundry machines. Notwithstanding these, there were few who felt unsafe and there was a certain degree of optimism about future improvements, including probably the prospect of moving to another dwelling expressed by both the Greek-Orthodox and Pentecostals.

There were no major income differences between the Greek-Orthodox and Pentecostals, but the low incomes of Jehovah's Witnesses are noticeable. The latter ones and the non-religious also had beneath average expenses. Pentecostals, Adventists and Jehovah's Witnesses admitted postponing utility payments during the previous 12 months. Additionally, significant proportions of Pentecostals, Adventists and Jehovah's 
Witnesses could not afford and adequate level of heating their homes. Among the Greek-Orthodox, there were single persons who were not able to manage by themselves.

In general, the income and dwelling expense-related problems appear to invite more attention from the Adventist, Pentecostal and Jehovah's Witnesses communities and those of single elders from the Greek-Orthodox one. Pentecostals, Jehovah's Witnesses and the non-religious had the lowest food budgets. Almost half of Pentecostals were buying food on credit, fact that can signal a scarcity of income for these communities. The quality of nourishment associated with prepared food was better for Pentecostals and Jehovah's Witnesses of which almost a third consumed it two or three times a week. The general quality of food as reflected in the daily amount of animal protein consumed, paradoxically, was better for Jehovah's Witnesses. Nevertheless, the connection between religious confession and diet should be studied further since it may very well be dependent on particular rituals and traditions of each religion. Table 1 presents a synthetic religion-based distribution model for some problems concerning the quality of life, which are of concern in our study and conclusions.

Table 1: A possible religion-based distribution model for some problems concerning the quality of life

\begin{tabular}{|c|c|c|c|}
\hline \multirow{2}{*}{$\begin{array}{l}\text { Religious } \\
\text { Confessions }\end{array}$} & \multicolumn{3}{|c|}{$\begin{array}{c}\text { Problems } \\
(\bullet \text { less than average })\end{array}$} \\
\hline & $\begin{array}{c}\text { Dwelling } \\
\text { (Personal living } \\
\text { space) }\end{array}$ & Income & Food Budget \\
\hline Non-Religious & 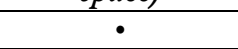 & $\cdot$ & • \\
\hline Greek-Orthodox & & & $\bullet$ \\
\hline \multicolumn{4}{|l|}{ Greek-Catholic } \\
\hline Romano-Catholic & & & $\cdot$ \\
\hline Protestant & $\bullet$ & $\bullet$ & \\
\hline Baptist & & $\bullet$ & $\bullet$ \\
\hline Pentecostal & & $\bullet$ & $\bullet$ \\
\hline Adventist & $\bullet$ & $\bullet$ & \\
\hline Jehovah's Witness & & $\cdot$ & $\bullet$ \\
\hline "Other" & & & \\
\hline
\end{tabular}

Source: Author's own work.

Table 1 suggests both the suitability of a strategic ecumenism and of more involvement of the religious leader as a community catalyst (Buțiu, 2015). Concerning ecumenism, there are at lest two meanings of the term that are drawing our attention: 1) "knowing the Christians belonging to each confession" and 2) "the collaboration of different confessions' representatives in dealing with the existing social problems" (Crețu, 2014: 535). The second connotation implies the collaboration towards solving certain punctual problems, but also towards managing long-term problems, in which case one 
can think of a strategic ecumenism. Of course, communities cannot remain outside these strategies, fact which suggests the use of community development terms - that is development inside and through the community. Religious leaders can become true catalysts of the capacitating process, which is also a community self-discovery process.

As seen from our data, several problems are encountered by the non-religious respondents who live among religious people. Who could be in charge of them? It is maybe the time to promote a tighter alignment between the strategic ecumenism that has been mentioned and the local development strategies of a more or less secular nature.

One problem associated with urban spaces like the one under study is the more determinant nature of the ethnic factor than of the religious one. This aspect can be proven even by our data, but in our opinion, the excuse of the particular ethnic profile of certain communities that are confronted with quality of life problems cannot continue to be invoked indefinitely. From a sustainable intervention perspective, we believe one should leave aside the ethnic background when one invokes the necessity of a strategic ecumenism. This is also the reason we did not emphasize in this study the role of the ethnic factor in determining the problems related to the quality of life in general or to dwelling, income or nourishment in particular.

\section{References}

Anyanwu, J. C. (2013). The correlates of poverty in Nigeria and policy implications. African Journal of Economic and Sustainable Development, 2(1), 23-52.

Butiu, C. A., \& Pascaru, M. (2014). Religious leadership and environmental concerns. A mining project case study. Journal for the Study of Religions and Ideologies, 13(39), 164-180.

Buțiu, C. A. (2015). Parish Priests-Community Development Catalysts in the Isolated Rural Space. Revista de Asistență Socială, 14(3), 75-85.

Crețu, C. (2014). The concept of Ecumenism. In Boldea, I. (coord.), Identities in Metamorphosis. Literature. Discourse and Multicultural Dialogue, Târgu Mureş: Arhipelag XXI Press, pp. 534540.

Diener, E., Tay, L. \& Myers, D. G. (2011). The religion paradox: If religion makes people happy, why are so many dropping out? Journal of Personality and Social Psychology, 101(6), 1278-1290.

Feather, N. T. (1974). Explanations of poverty in Australian and American samples: The person, society, or fate? Australian Journal of Psychology, 26(3), 199-216.

Gooren, H. (2002). Romano-Catholic and Non-Romano-Catholic Theologies of Liberation: Poverty, Self-Improvement, and Ethics Among Small-Scale Entrepreneurs in Guatemala City. Journal for the Scientific Study of Religion, 41(1), 29-45.

Gruber, J. H. (2005). Religious Market Structure, Religious Participation, and Outcomes: Is Religion Good for You? Working Paper 11377. Cambridge - Massachusetts: National Bureau of Economic Research.

Guiso, L., Sapienza, P., \& Zingales, L. (2003). People's opium? Religion and economic attitudes. Journal of Monetary Economics, 50(1), 225-282.

Hunt, M. O. (2002). Religion, Race/Ethnicity, and Beliefs about Poverty. Social Science Quarterly, 83(3), 810-831.

Jawad, R. (2008). Religion and Social Welfare in the Lebanon: Treating the Causes or Symptoms of Poverty? Journal of Social Policy, 38(1), 141-156. 
Kahl, S. (2005). The Religious Roots of Modern Poverty Policy: Romano-Catholic, Lutheran, and Reformed Protestant Traditions Compared. European Journal of Sociology, 46(1), 91-126.

Keister, L.A. (2008). Conservative Protestants and Wealth: How Religion Perpetuates Asset Poverty. American Journal of Sociology, 113(5), 1237-1271.

Lepianka, D., Gelissen, J., \& van Oorschot, W. (2010). Popular Explanation of Poverty in Europe. Acta Sociologica, 53(1), 53-72.

Ludwig, J. \& Mayer, S. (2006). Culture and the Intergenerational Transmission of Poverty: The Prevention Paradox. The Future of Children, 16(2), 175-196.

Marina, L. (2010). Lumea Nouă - cartier dezavantajat. Studiu sociologic și plan de acțiune, Raport de cercetare final. Alba Iulia: Alba Iulia City Hall \& “1 Decembrie 1918” University.

Mariz, C. (1992). Religion and Poverty in Brazil: A Comparison of Romano-Catholic and Pentecostal Communities. Sociological Analysis, 53 (Special Presidential Issue Conversion, Charisma, and Institutionalization), S63-S70.

Moldovan, S. (2010). Predictori ai orientării antreprenoriale în micro-regiunea Livezile-Rimetea. In Pascaru, M. (coord.), Inteligență teritorială, matrice comunitară și guvernare participativă, Alba Iulia: Editura Aeternitas, pp. 114-129.

Achia, T. N., Wangombe, A., \& Khadioli, N. (2010). A logistic regression model to identify key determinants of poverty using demographic and health survey data. European Journal of Social Sciences, 13(1), 38-45.

Offutt, S., Probasco, L., \& Vaidyanathan, B. (2016). Religion, Poverty and Development. Journal for the Scientific Study of Religion, 55(2), 207-215.

Pascaru, M. \& Buțiu, C. A. (2009). Civil Society, Public Participation, and Religious Affiliation. Exploratory Investigations in the Livezile-Rimetea Area (Apuseni Mountains, Romania). Journal for the Study of Religions and Ideologies, 8(22), 150-170.

Peterson, M. \& Webb, D. (2006). Religion and Spirituality in Quality of Life Studies. Applied Research in Quality of Life, I(1), 107-116.

Sandu, D. (2015). The Social Space of Transition. A Sociological Approach on Romania. Madrid/London/New York: Niram Art Editorial.

Thorat, A. (2010). Ethnicity, Caste and Religion: Implications for Poverty Outcomes. Economic \& Political Weekly, XLV(51), 47-53. 